\title{
REDESIGN OF CUSTOMS VALUE PROOF MECHANISM BY CUSTOMS ADMINISTRATION ACCORDING TO WTO PROVISIONS (DISPUTE STUDY AT TAX COURT)
}

\author{
Ardiansyah \\ Departement of Law, IBLAM School of Law \\ Jalan Kramat Raya No.25, Jakarta Pusat
}

\begin{abstract}
Abstrack
Based on the analysis of the 2018 Tax Court decisions in customs value disputes, the judges' considerations in the decisions that reject customs decisions were mostly due to the appeal applicant is able to prove the correctness of the transaction value at trial based on supporting documents such as sales contracts, purchase orders, proof of payment, and bookkeeping. However, if there is any evidence that is incomplete or there is a different value, it is likely that the appeal is rejected. In order to explore how to prove customs value from normative and empirical aspects, research is compiled on the legal aspects of proving based on the provisions of WTO Agreemet on Implementation of Article VII of GATT. Normative juridical research result leads to one conclusion that the provisions for reversing the burden of proof are stipulated in the WTO Valuation Agreement, namely in article 17 and WTO Ministerial Decission 6.1. In addition, Technical Committee on Customs Valuation World Customs organization has published Case Study 13.1: "Application of Decision 6.1 of the Committee on Customs valuation".
\end{abstract}

Keywords: customs value, evidence, tax court, disputes 


\title{
REDESAIN MEKANISME PEMBUKTIAN NILAI PABEAN OLEH ADMINISTRASI KEPABEANAN SESUAI KETENTUAN WTO (STUDI SENGKETA DI PENGADILAN PAJAK)
}

\author{
Ardiansyah \\ Program Studi Sarjana Hukum, Sekolah Tinggi Ilmu Hukum IBLAM \\ Jalan Kramat Raya No. 25 Jakarta Pusat
}

\section{Intisari}

Berdasarkan analisa terhadap putusan-putusan Pengadilan Pajak tahun 2018 dalam sengketa nilai pabean, pertimbangan hakim dalam putusan-putusan yang mengalahkan DJBC sebagian besar disebabkan pemohon banding dapat membuktikan kebenaran nilai transaksi di persidangan berdasarkan dokumen-dokumen pendukung nilai transaksi seperti Sales Contract, Purchase Order, bukti pembayaran, dan pembukuan. Namun apabila terdapat bukti-bukti yang tidak lengkap atau terdapat nilai yang berbeda kemungkinan besar permohonan banding ditolak. Dalam rangka menggali bagaimana pembuktian nilai pabean dari aspek normatif dan empiris maka disusun penelitian atas aspek hukum pembuktian nilai babean berdasarkan ketentuan WTO Agreemet on Implementation of Article VII of GATT. Analisis normatif dalam penelitian ini membatasi aspek hukum pembuktian sebagai dasar penetapan nilai pabean oleh pejabat Bea dan Cukai dan Pengadilan Pajak. Penelitian yuridis normatif terkait hukum pembuktian menghasilkan kesimpulan bahwa ketentuan pembalikan beban pembuktian tercantum dalam WTO Valuation Agreement yaitu pada pasal 17 dan WTO Ministerial Decission 6.1 yang telah diratifikasi dengan UU No.7 tahun 1994 tentang Pengesahan WTO. Selain itu, Komite Teknis Penilaian Bea Cukai Organisasi Bea Cukai Dunia telah menerbitkan Studi Kasus 13.1: "Penerapan Keputusan 6.1 dari Komite Penilaian Bea Cukai".

Keywords: Nilai Pabean, pembuktian, pengadilan pajak, sengketa 


\section{A. Pendahuluan}

Angka kekalahan Direktorat Jenderal Bea Cukai (DJBC) dalam sengketa nilai pabean di Pengadilan Pajak masih tinggi. Dari banyaknya volume sengketa nilai pabean yang diajukan, kekalahan mencapai lebih dari $60 \%$ dipihak Bea Cukai.

Tabel 1

Hasil Putusan Banding Nilai Pabean Tahun 2018

\begin{tabular}{|c|c|c|c|}
\hline $\begin{array}{l}\text { Jenis } \\
\text { Putusan }\end{array}$ & $\begin{array}{l}\text { Jumlah } \\
\text { Putusan }\end{array}$ & $\begin{array}{c}\text { Persentas } \\
\text { e }\end{array}$ & $\begin{array}{l}\text { Pertimbangan } \\
\text { Hakim }\end{array}$ \\
\hline Menolak & 167 & 16,28 & $\begin{array}{l}\text { Pemohon banding } \\
\text { tidak dapat } \\
\text { membuktikan secara } \\
\text { sah dan meyakinkan } \\
\text { kebenaran harga } \\
\text { yang sebenarnya } \\
\text { atau yang } \\
\text { seharusnya dibayar }\end{array}$ \\
\hline $\begin{array}{l}\text { Membatalk } \\
\text { an } \\
\text { Keputusan } \\
\text { DJBC }\end{array}$ & 11 & 1,07 & $\begin{array}{l}\text { formal penerbitan } \\
\text { keputusan tidak } \\
\text { terpenuhi }\end{array}$ \\
\hline $\begin{array}{l}\text { Mencabut } \\
\text { Banding }\end{array}$ & 6 & 0,58 & $\begin{array}{l}\text { Dicabut pemohon } \\
\text { banding }\end{array}$ \\
\hline $\begin{array}{l}\text { Tidak } \\
\text { Dapat } \\
\text { Diterima } \\
\text { (TDD) }\end{array}$ & 135 & 13,16 & $\begin{array}{l}\text { Jangka waktu } \\
\text { pengajuan banding } \\
\text { lebih dari } 60 \text { hari } \\
\text { sejak tanggal } \\
\text { pengiriman } \\
\text { keputusan keberatan } \\
\end{array}$ \\
\hline $\begin{array}{l}\text { Mengabulk } \\
\text { an } \\
\text { Seluruhnya }\end{array}$ & 668 & 65,11 & $\begin{array}{l}\text { Pemohon } r \text { banding } \\
\text { dapat membuktikan } \\
\text { secara sah dan } \\
\text { meyakinkan } \\
\text { kebenaran } \\
\text { yang harga } \\
\text { atau sebenarnya } \\
\text { seharusnya dibayar }\end{array}$ \\
\hline $\begin{array}{l}\text { Mengabu } \\
\text { lkan } \\
\text { Sebagian }\end{array}$ & 39 & 3,80 & $\begin{array}{l}\text { Nilai pabean } \\
\text { sesuai pemohon } \\
\text { banding; } \\
\text { klasifikasi sesuai } \\
\text { terbanding }\end{array}$ \\
\hline Total & 1026 & 100,00 & \\
\hline
\end{tabular}

\section{Sumber: DJBC, diolah penulis}

Berdasarkan analisa terhadap putusan-putusan Pengadilan Pajak tahun 2018 dalam sengketa nilai pabean Pertimbangan hakim dalam putusan-putusan yang mengalahkan DJBC sebagian besar disebabkan pemohon banding dapat membuktikan kebenaran nilai transaksi di persidangan berdasarkan dokumendokumen pendukung nilai transaksi seperti Sales Contract, Purchase Order, bukti pembayaran, dan pembukuan. Namun apabila terdapat bukti-bukti yang tidak lengkap atau terdapat nilai yang berbeda kemungkinan besar permohonan banding ditolak. Dengan demikian yang menjadi inti pokok permasalahan sengketa nilai pabean adalah adanya perbedaan keyakinan ditingkat keberatan dan Pengadilan Pajak terhadap pembuktian nilai pabean.

Terkait dengan penelitian penetapan nilai pabean maka hal tersebut tidak terlepas dari hukum perdagangan internasional yang digariskan oleh World Trade Organization (WTO). Ketentuan penetapan nilai pabean yang disepakati dalam pembentukan WTO adalah Nilai Transaksi barang impor sebagai dasar nilai pabean. Alasan penggunaan Nilai Transaksi sebagaimana dimaksud dalam Pendapat Pendahuluan Umum (General Introductory Commentary) dari Agreement on Implementation of Article VII of GATT 1994 di antaranya adalah (1) fairness, keseragaman, dan sistem yang netral dalam menetapkan nilai barang untuk tujuan kepabeanan sehingga dapat menghilangkan nilai pabean yang bersifat arbiter atau fiksi (seperti halnya sistem BDV dengan harga patokannya) dan (2) bahwa nilai pabean harus berdasarkan kriteria yang sederhana dan sama untuk semua pihak 
(equitable) dan konsisten dengan praktik perdagangan pada umumnya. ${ }^{1}$

Sengketa di bidang kepabeanan merupakan bagian dari sengketa pajak ${ }^{2}$ sebagaimana diatur dalam Pasal 1 angka 2 Undang-undang Nomor 14 tahun 2002 tentang Pengadilan Pajak. Ketentuan tersebut mendefinisikan pajak sebagai semua jenis pajak yang dipungut oleh pemerintah pusat termasuk bea masuk dan cukai, serta pajak yang dipungut oleh pemerintah daerah, berdasarkan peraturan perundang-undangan yang berlaku. $^{3}$ Proses yang sangat penting dalam penyelesaian sengketa adalah proses pembuktian. Para pihak yang bersengketa berusaha membuktikan dalilnya untuk meyakinkan pembuat keputusan. Pembuktian bertujuan untuk menetapkan hukum di antara kedua pihak yang menyangkut suatu hak sehingga diperoleh suatu kebenaran yang memiliki nilai kepastian, keadilan dan kepastian hukum. ${ }^{4}$

Sebagaimana dinyatakan oleh Mertokusumo inti dari seluruh pemeriksaan di persidangan adalah pembuktian. Membuktikan berarti memberi dasar yang cukup kepada hakim untuk memberi kepastian tentang kebenaran peristiwa yang diajukan. ${ }^{5}$ Bukti yang digunakan di Pengadilan Pajak adalah surat atau tulisan, keterangan ahli, keterangan

\footnotetext{
General Introductory Commentary, Agreement on Implementation of Article VII of GATT 1994.

2 Indonesia, Undang - Undang Tentang Pengadilan Pajak, UU No. 14 tahun 2002, LN No.27 Tahun 2002, Pasal 1 angka 5.

${ }^{3}$ Ibid. Pasal 1 angka 5

4 Machmud, Syahrul, Hukum Acara Khusus pada Pengadilan Hubungan Industrial, (Yogyakarta: Graha Ilmu, 2014), 119.

5 Mertokusumo, Soedikno, Hukum Acara Perdata, (Yogyakarta: Liberty, 2002), 128.
}

para saksi, pengakuan para pihak; dan/atau pengetahuan hakim. ${ }^{6}$ Penelitian terkait hukum pembuktian nilai pabean sangat penting guna memberikan kepastian hukum dan keadilan serta kemanfaatan hukum bagi masyarakat secara umum, sehingga dapat menjadi dasar hukum yang jelas dan pasti bagi importir dan pejabat bea cukai serta Pengadilan Pajak dalam melakukan penetapan nilai pabean.

Sebagaimana telah dikemukakan di atas, dari banyaknya volume sengketa nilai pabean yang diajukan ke Pengadilan Pajak masih dominan kekalahan dipihak bea cukai. Rata-rata lebih dari $60 \%$ kekalahan dialami Bea dan Cukai di Pengadilan Pajak. Dari jumlah sengketa tersebut data menunjukkan masih tingginya angka kekalahan DJBC dalam sengketa nilai pabean. Berdasarkan penelitian atas data putusan banding yang memenangkan Bea Cukai diketahui bahwa alasan Majelis Hakim menolak banding karena Pemohon Banding tidak dapat membuktikan nilai pabean yang diberitahukan adalah nilai transaksi yang sebenarnya atau yang seharusnya dibayar.

Pertimbangan tersebut mencerminkan dianutnya asas pembalikan beban pembuktian oleh Majelis Hakim, dimana majelis Hakim menghendaki agar pihak importir atau Pemohon banding dapat membuktikan kebenaran nilai transaksi barang impornya. Namun demikian mayoritas majelis Hakim hanya membebankan pembuktian kepada Pemohon sampai dengan bukti pembayaran saja, majelis Hakim tidak meminta untuk menunjukkan bukti-bukti pembukuan, pencatatan, dan penjualan barang ke konsumen dalam negeri serta data

${ }^{6}$ Lihat : Pasal 69 UU Pengadilan Pajak 
perpajakan untuk membukti kebenaran nilai transaksi Pemohon banding.

Bagaimana seharusnya mekanisme penetapan nilai pabean dan ketentuan pembuktian nilai pabean menjadi hal yang sangat urgent untuk diteliti. Selanjutnya, berdasarkan penelitan aspek hukum penetapan dan pembuktian nilai pabean yang ideal, dilakukan langkah-langkah perbaikan dari segi peraturan perundangundangan maupun dari segi struktur organisasi dan sumber daya manusia. Pada akhirnya diharapkan hasil penelitian ini dapat menurunkan tingkat kekalahan Banding atas penetapan nilai pabean dan meningkatkan kualitas penetapan nilai pabean, keputusan keberatan atas penetapan nilai pabean.

Adapun Rumusan masalah yang akan penulis bahas dalam tulisan ini adalah :

1. Bagaimana ketentuan pembuktian nilai pabean dalam UU Kepabeanan (domestic law) dan ketentuan WTO.

2. Bagaimana mekanisme penetapan nilai pabean yang seharusnya sesuai ketentuan WTO Agreemet on Implementation of Article VII of GATT.

\section{B. Metode Penelitian}

Penelitian hukum dari pertanyaan tersebut dilakukan dengan dua pendekatan yaitu: pertama, pendekatan analitis kasus (analytical approach) dari putusan-putusan Pengadilan untuk mengetahui alasan-alasan para pihak yang bersengketa dan pertimbangan hakim. Kedua, pendekatan peraturan perundang-undangan

(statute approach) untuk meneliti permasalahan dalam muatan norma hukum yang menjadi dasar tindakan pejabat Bea dan Cukai.
Telah diketahui terdapat inharmonisasi, inkonsistensi, dan ketidaksesuaian materi peraturan perundangan-undangan ditingkat implementasi operasional dengan UU Kepabeanan dan ketentuan WTO/ Article VII GATT. Dari dua pendekatan tersebut dapat diketahui bagaimana mekanisme penetapan nilai pabean yang seharusnya. Selanjutnya dirumuskan Peraturan Perundangundangan yang harus dilakukan perbaikan guna terlaksananya konsep ideal penetapan nilai pabean.

\section{Analisis dan Diskusi}

Terkait dengan penelitian penetapan nilai pabean maka hal tersebut tidak terlepas dari hukum perdagangan internasional yang digariskan oleh World Trade Organization (WTO). Ketentuan penetapan nilai pabean yang disepakati dalam pembentukan WTO adalah Nilai Transaksi barang impor sebagai dasar nilai pabean. Alasan penggunaan Nilai Transaksi sebagaimana dimaksud dalam Pendapat Pendahuluan Umum (General Introductory Commentary) dari Agreement on Implementation of Article VII of GATT 1994 di antaranya adalah (1) fairness, keseragaman, dan sistem yang netral dalam menetapkan nilai barang untuk tujuan kepabeanan sehingga dapat menghilangkan nilai pabean yang bersifat arbiter atau fiksi (seperti halnya sistem BDV dengan harga patokannya) dan (2) bahwa nilai pabean harus berdasarkan kriteria yang sederhana dan sama untuk semua pihak (equitable) dan konsisten dengan praktik perdagangan pada umumnya. ${ }^{7}$

\footnotetext{
7 General Introductory Commentary, Agreement on Implementation of Article VII of GATT 1994.
} 
Dalam kajian terhadap Hukum Perdagangan Internasional, Garcia menyebutkan bahwa hukum perdagangan internasional harus dirumuskan untuk melindungi kesetaraan moral seluruh individu yang terpengaruh oleh adanya perdagangan internasional. Berdasarkan penelaahan Garcia dalam bukunya Trade and Inequality: Economic, Justice and The Developing World dikemukakan bahwa ketidaksejajaran lingkungan internasional dalam bidang sosial dan ekonomi hanya dapat dikatakan sebagai suatu keadaan yang adil dalam hal ketidaksejajaran tersebut memberikan suatu keadaan yang lebih baik bagi negara-negara yang kurang beruntung dalam bidang sosial dan ekonomi tersebut. ${ }^{8}$

\section{Ketentuan Pembuktian Nilai Pabean dalam UU Kepabeanan}

Dalam UU Kepabeanan terdapat ketentuan pembalikan beban pembuktian (reversal the burden of proof) atau pergeseran beban pembuktian (shifting the burden of proof) kepada pihak impotir atau eksportir sebagaimana tercantum dalam pasal 84 UU Kepabeanan dan penjelasannya sebagai berikut:

\section{Pasal 84}

(1) Pejabat bea dan cukai berwenang meminta kepada importir atau eksportir untuk menyerahkan buku, catatan, surat menyurat yang bertalian dengan impor atau ekspor, dan mengambil contoh barang untuk pemeriksaan pemberitahuan pabean.

\footnotetext{
8 Frank J Garcia, Trade, Inequality, and Justice: Toward a Liberal Theory of Just Trade, (New York: Transnational Publishers, 2003). Hlm. 72
}

(2) Pengambilan contoh barang dapat pula dilakukan atas permintaan importir.

Penjelasan Pasal 84

Ayat (1)

Ayat ini memberikan kewenangan kepada pejabat bea dan cukai untuk meminta kepada Importir atau eksportir untuk :

a. menyerahkan buku, catatan, dan surat menyurat yang berkaitan dengan:
1. pembelian;
2. penjualan;
3. impor;
4. ekspor,
5. persediaan; atau
6. pengiriman barang yang bersangkutan.

b. menyerahkan contoh barang untuk tujuan pemeriksaan pemberitahuan.

Atas penyerahan yang dilakukan oleh importir atau eksportir sebagaimana

dimaksud di atas, diberikan tanda bukti penerimaan oleh pejabat bea dan cukai. Dalam hal permintaan pejabat bea dan cukai sebagaimana dimaksud di atas tidak dipenuhi pejabat bea dan cukai akan melakukan penetapan tarif dan/atau nilai pabean berdasarkan data yang ada, dan mungkin akan mengakibatkan kerugian bagi yang bersangkutan.

Dalam Penjelasan Pasal 84 UU Kepabeanan tersebut dinyatakan bahwa : "Dalam hal permintaan pejabat bea dan cukai sebagaimana dimaksud di atas tidak dipenuhi pejabat bea dan cukai akan melakukan penetapan tarif dan/atau nilai pabean berdasarkan data yang ada". Rumusan penjelasan Pasal 84 berdasarkan teori hukum pembuktiant merupakan ketentuan pembalikan beban pembuktian (reversal the burden of proof) atau pergeseran beban pembuktian (shifting the burden of proof). 
Namun penjelasan tidak dapat digunakan sebagai dasar hukum untuk membuat peraturan lebih lanjut dan tidak boleh mencantumkan rumusan yang berisi norma. ${ }^{9}$ Penjelasan tidak menggunakan rumusan yang isinya memuat perubahan terselubung terhadap ketentuan Peraturan Perundang-undangan. ${ }^{10}$

Dalam Peraturan Menteri Keuangan Nomor 160/PMK. 04/2010 Tentang Nilai Pabean Untuk Penghitungan Bea Masuk (PMK 160/2010) sebagaimana diubah terakhir dengan Peraturan Menteri Keuangan Nomor 62/PMK.04/2018 juga terdapat ketentuan pembebanan pembuktian yaitu Pasal 28 dan Pasal 31. ${ }^{11}$

Pasal 28 ayat (5) PMK 160/2010 menyatakan:

"Dalam hal importir tidak memenuhi permintaan sebagaimana dimaksud pada ayat (2) sehingga nilai transaksi tidak dapat diyakini kebenaran dan keakuratannya, Pejabat Bea dan Cukai menetapkan nilai pabean berdasarkan nilai transaksi Barang Identik sampai dengan metode pengulangan (fallback) yang diterapkan sesuai hierarkipenggunaannya."

Pasal 28 ayat (5) PMK 160/2010 menyatakan:

"Apabila importir tidak memenuhi permintaan sebagaimana dimaksud pada ayat (2), Direktur Jenderal dapat menggunakan data yang tersedia di

9 Rahmat Trijono, Dasar-dasar Ilmu Pengetahuan Perundangan-undangan. (Jakarta: Penerbit Papas Sinar Sinanti, 2013), hlm.161.

10 Undang - Undang No. 12 Tahun 2011 Tentang Pembentukan Peraturan PerundangUndangan, Lampiran I: 176.

11 Peraturan Menteri Keuangan Republik Indonesia tentang Nilai Pabean untuk Penghitungan Bea Masuk, Peraturan Menteri Keuangan nomor PMK-160/PMK.04/2010 dalam Daerah Pabean untuk menetapkan kembali nilai pabean."

Berdasarkan teori hukum pembuktian ketentuan dalam Pasal 28 dan 31 PMK 160/2010 tersebut dikategorikan sebagai pembalikan beban pembuktian (shifting the burden of proof) kepada pihak impotir. Ketentuan tersebut menyatakan apabila pada saat pemeriksaan pemberitahuan pabean importir tidak memenuhi permintaan pejabat bea dan cukai atau Direktur Jenderal untuk menyerahkan semua informasi, dokumen, dan/atau pernyataan yang diperlukan dalam rangka penentuan nilai pabean maka Pejabat Bea dan Cukai menetapkan nilai pabean berdasarkan nilai transaksi barang identik sampai dengan metode pengulangan sesuai hierarki penggunaannya dan Direktur Jenderal dapat menggunakan data yang tersedia di dalam Daerah Pabean untuk menetapkan kembali nilai pabean.

\section{Ketentuan Pembuktian Nilai Pabean menurut WTO/ Article VII GATT}

Mengacu pada Ketentuan WTO/ Article VII GATT, seharusnya keputusan pejabat yang tidak menerima nilai pabean dari importir ketika meragukan pemberitahuan tetap mengacu pada WTO Valuation Agreement pada General Introductory Commentary, Paragraf 2 yang mensyaratkan perlunya dilakukan suatu proses konsultasi antara pihak Pabean dengan Importir dalam hal nilai pabean tidak dapat ditetapkan berdasarkan ketentuan Pasal 1 (nilai transaksi tidak dapat diterima sebagai nilai pabean). Dalam negosiasi Putaran Uruguay telah diputukan adopsi dari "Decision regarding cases where customs administrations have reasons to doubt the truth or accuracy of the declared 
value" (Decision 6.1 berdasarkan Article 17).$^{12}$

Decision 6.1 ini bertujuan untuk menjawab permasalahan yang timbul dalam situasi-situasi tertentu dimana bea dan cukai memiliki alasan untuk meragukan kebenaran dan akurasi dari nilai yang diberitahukan. Apabila pada saat melakukan penetapan nilai pabean bea dan cukai memiliki alasan untuk meragukan kebenaran dan akurasi dari nilai yang diberitahukan, maka bea dan cukai harus memberitahukan kepada importir alasan-alasan mengapa ia meragukan kebenaran dari nilai yang diberitahukan tersebut. Importir juga harus diberi kesempatan yang cukup untuk memberi tanggapannya. Kemudian apabila setelah importir memberikan tanggapannya bea dan cukai masih tetap meragukan kebenaran nilai yang diberitahukan tersebut, maka bea dan cukai dapat memutuskan bahwa nilai pabean barang yang bersangkutan tidak dapat ditetapkan dengan menggunakan caracara sesuai Pasal 1 atau metode nilai transaksi. Dalam Decision 6.1 tersebut apabila pabean masih memiliki keraguan yang masuk akal, yaitu, dianggap bahwa nilai pabean barang tidak dapat ditentukan berdasarkan nilai transaksi, dan dengan demikian melanjutkan untuk menggunakan metode penilaian alternatif dari WTO Valuation Agreement, yang harus diikuti secara ketat urutannya. ${ }^{1}$

Sejalan dengan Pasal 17 dari WTO Valuation Agreement dan Ministerial Decision 6.1 yang membahas ketentuan tentang "beban pembuktian" ini secara jelas menyebutkan bahwa untuk maksud-maksud yang berkaitan dengan nilai pabean administrasi bea dan cukai

${ }^{12}$ WTO, Ministrial Decision 6.1

13 Ibid. diperbolehkan untuk meminta informasi atau mengajukan pertanyaan yang berkaitan dengan kebenaran atau akurasi dari setiap pernyataan, dokumen atau pemberitahuan yang diberikan kepada bea dan cukai. Apabila ketika memeriksa suatu nilai pabean yang diberitahukan bea dan cukai memiliki keraguan akan kebenaran informasi tertentu yang tertera di dalamnya atau dokumen yang disertakan untuk mendukung informasi tersebut maka bea dan cukai dapat meminta importir bersangkutan agar memberikan penjelasan yang lebih lengkap atau memberikan dokumen atau bukti tambahan lainnya. ${ }^{14}$

Maksudnya di sini adalah agar importir mampu untuk membuktikan bahwa nilai pabean yang diberitahukannya itu benar-benar merupakan jumlah keseluruhan yang dibayarkan atau yang seharusnya dibayar dan telah memenuhi pula ketentuan tentang biaya-biaya tambahan seperti yang disebutkan dalam Pasal 8 WTO Valuation Agreement. $^{15}$ Jika importir tidak memberikan penjelasan tambahan yang diminta atau setelah mendapatkan penjelasan tambahan Itu bea dan cukai tetap memiliki keraguan tentang kebenaran nilai pabean yang diberitahukan maka bea dan cukai dapat membuat keputusan bahwa nilai pabean barang impor bersangkutan tidak dapat ditentukan dengan ketentuan yang diatur oleh Pasal 1 WTO Valuation Agreement. ${ }^{16}$

Sebelum keputusan akhir dibuat, Pejabat Bea dan Cukai harus memberitahukan kepada importir

\footnotetext{
${ }^{14}$ Pasal 17 WTO Valuation Agreement

${ }^{15}$ WTO, Ministrial Decision 6.1,

${ }^{16}$ ASEAN Customs Valuation Guide. Halaman 47.
} 
(bahkan mungkin dalam pemberitahuan tertulis jika memang diminta) alasanalasannya dalam meragukan informasi tertentu dalam pemberitahuan tersebut atau dokumen pendukung yang disertakan. Berkaitan dengan ini importir akan diberikan waktu untuk memberikan tanggapan. Dan akhirnya bea dan cukai harus memberitahu importir tentang keputusan akhirnya serta alasan-alasan yang mendasari keputusan itu dibuat. ${ }^{17}$

Dalam melaksanakan ketentuan Pasal 17 WTO Valuation Agreement di atas, bea dan cukai memiliki hak untuk meminta kerjasama penuh dari importir ketika melakukan penelitiam atas kebenaran atau akurasi dari setiap pernyataan, dokumen atau pemberitahuan yang disampaikan. ${ }^{18}$

Berkaitan dengan tatacara penerapan Ministerial Decision 6.1, Technical Committee on Customs Valuation (TCCV) mengeluarkan Case Study 13.1. Studi Kasus 13.1 dari Technical Committee on Customs Valuation adalah satu petunjuk yang mengatur pelaksanaan dari ${ }^{19}$ WCO telah memberikan panduan teknis (best practice) dalam melakukan proses nilai pabean berdasarkan Case Study 13.1.

Berdasarkan ketentuan WTO Valuation Agreement, ministerial decision 6.1 dan case study 13.1 dimungkinkan diterapkannya pembalikan beban pembuktian (reversal the burden of proof) atau pergeseran beban pembuktian (shifting the burden of proof) kepada pihak impotir. Apabila pada saat pemeriksaan pemberitahuan pabean importir tidak memenuhi permintaan bea dan cukai untuk menyerahkan

${ }^{17}$ ASEAN Customs Valuation Guide. Ibid.

${ }^{18}$ ASEAN Customs Valuation Guide. Ibid.

${ }^{19}$ ASEAN Customs Valuation Guide. Ibid. semua informasi, dokumen, dan/atau pernyataan yang diperlukan dalam rangka penentuan nilai pabean maka nilai transaksi barang impor yang diberitahukan oleh Pemohon tidak dapat diterima sehingga digunakan metode alternative.

Namun demikian dalam menetapkan nilai pabean dilarang menggunakan Prohibited method atau aturan "Metode larangan" yang tercantum dalam Pasal 7 Agreement (dalam metode "fall back") yang merupakan referensi dalam sistem penilaian pabean. Dalam pasal 7 ayat (2) WTO Valuation Agreement jo. Pasal 15 ayat (7) UU Kepabeanan terdapat aturan "Metode larangan" dalam penentuan nilai pabean oleh Administrasi Pabean, yang menyebutkan : ${ }^{20}$

Nilai pabean tidak diijinkan ditetapkan menurut ketentuan Pasal ini berdasarkan:

(a) harga jual di negara pengimpor bagi barang yang diproduksi di negara tersebut;

(b) suatu sistem yang menentukan apabila terdapat dua alternatip nilai, ditetapkan nilai yang lebih tinggi;

(c) harga pasaran dalam negeri negara pengekspor;

(d) biaya produksi; selain dari nilai yang dihitung dengan metode komputasi yang telah ditentukan untuk barang identik atau serupa berdasarkan ketentuan Pasal 6;

(e) harga barang ekspor ke suatu negara selain negara pengimpor;

(f) nilai pabean minimal; atau

(g) nilai yang ditetapkan dengan sewenang-wenang atau harga fiktif.

${ }^{20}$ WTO, Opcit., Pasal 7 ayat (2) 
Penggunaan salah satu dari ketujuh larangan tersebut akan berdampak pada ketidaksesuaian penerapan ketentuan WTO Valuation Agreement, bahkan pada akhirnya akan dianggap sebagai tindakan non-tariff barrier yang bertentangan dengan prinsip-prinpsip WTO sebagaimana diuraikan pada kajian literatur di atas. ${ }^{21}$

Mengingat peraturan mengenai Nilai Pabean dalam WTO Valuation Agreement dan Keputusan Komite Teknis Nilai Pabean WTO dan WCO telah cukup jelas dan rinci mengatur teknis dan tatacara penetapan nilai pabean maka peraturan nasional (peraturan teknis nilai pabean) yang menjelaskan mengenai tata cara penetapan nilai pabean harus diadakan review agar penetapan nilai pabean dapat berjalan sesuai dengan prinsipprinsip International Best Practice. Berdasarkan Case Study 13.1. proses ideal penetapan nilai pabean seharusnya dilakukan dalam proses audit (post clearance audit). Metode audit yang dilakukan dengan langkahlangkah sebagai berikut:

1. Melakukan analisis sebelum dilakukan audit terhadap profil importir

2. Melakukan analisis sebelum dilakukan audit terhadap kewajaran harga (test value) dilakukan berdasarkan data harga barang identik dari berbagai sumber dengan pemasokpemasok dan importir-importir yang berbeda termasuk dari sumber internet.

${ }^{21}$ Sheri Rosenow, Brian J. O'Shea, 2010, “A Handbook on WTO Customs Valuation Agreement - World Trade Organization", hlm. 9.
3. Melakukan proses permintaan data dan konsultasi dengan importir

4. Memanfaatkan pertukaran data dengan negara eksportir (apabila telah disepakati perjanjian pertukaran data)

5. Melaksanakan audit ke perusahaan untuk memeriksa data penjualan lokal, catatan akuntansi, pembukuan dan laporan keuangan

6. Melakukan analisa kewajaran terhadap keuntungan perusahaan dibandingkan dengan harga jual kembali.

7. Melakukan penetapan nilai pabean apabila dalam proses audit menemukan reasonable doubt tentang kebenaran atau akurasi dari nilai transaksi berdasarkan bukti nyata obyektif dan terukur.

Dari uraian di atas, dikaitkan dengan teori pembuktian dan teori keadilan dalam Hukum Perdagangan Internasional, penetapan nilai pabean harus benar-benar didukung bukti yang kuat agar penerapan nilai pabean sejalan dengan WTO Valuation Agreement sehingga Indonesia terhindar dari tuduhan melakukan proteksionisme (non-tariff barrier) yang dapat menyebabkan tindakan pembalasan (reprocity) dari Negaranegara anggota WTO sehingga mengganggu hubungan dagang dan ketertiban dunia sebagai tujuan Hukum Perdagangan Internasional dan dampak hukum lainnya dalam wilayah hukum nasional yang dapat menjerat Pejabat Bea dan Cukai yang melakukan penetapan nilai pabean. Seyogyanya, dalam melakukan penetapan nilai pabean, Bea dan Cukai harus mencari alat-alat bukti yang cukup untuk 
menetapkan nilai pabean dan melakukan permintaan data serta konsultasi kepada pihak importir sehingga penetapan yang dibuat oleh DJBC memenuhi ketentuan UU Kepabeanan dan WTO.

\section{Langkah-langkah Perbaikan Implementasi Penetapan Nilai Pabean}

Secara umum penyebab kesulitan yang dialami Administrasi Pabean dinegara-negara berkembang adalah sebagaimana dijelaskan Luc De Wulf dan Jose B. Sokol dalam bukunya Customs Modernization Handbook, Washington, D.C., The World Bank, 2005 berdasarkan Kajian yang menyeluruh terhadap penerapan nilai pabean di Negara berkembang.

Sistem penilaian pabean telah menjadi subyek perjanjian internasional karena dapat menciptakan hambatan perdagangan. WTO Valuation Agreement mengamanatkan penggunaannya untuk semua anggota WTO. WTO Valuation Agreement menetapkan bahwa nilai pabean barang impor, sedapat mungkin, adalah nilai transaksi, yaitu, harga yang sebenarnya dibayar atau yang seharusnya dibayar untuk barang. Pelaksanaan WTO Valuation Agreement yang tepat dan sempurna mengharuskan perbaikan peraturan perundangundangan, reformasi prosedur administrasi, struktur organisasi dan halhal lainnya sebagai berikut: ${ }^{22}$

\section{a. Legislasi / Peraturan Perundang- undangan}

Sebagaimana rekomendasi Luc De Wulf dan Jose B. Sokol dalam bukunya Customs Modernization Handbook menyatakan bahwa ketentuan dalam

\footnotetext{
${ }^{22}$ Luc De Wulf, Jose B. Sokol, 2005, Customs Modernization Handbook, Washington, D.C., The World Bank, hlm.147
}

WTO Valuation Agreement perlu dimasukkan dalam hukum nasional. Proses legislasi dapat menentukan maksud yang sebenarnya dari WTO Valuation Agreement. Undang-undang perlu mengatur nilai pabean secara komprehensif, meliputi WTO Valuation Agreement dan interpretative notesnya, serta sejumlah ketentuan tertentu, seperti yang menyangkut penyesuaian tingkat perdangan, prosedur keberatan banding, pengeluaran sebelum penetapan, dan perlakuan biaya transportasi dan asuransi (sistem FOB atau CIF). ${ }^{23}$

Dengan demikian, UU Kepabeanan harus diperbaiki dengan memuat ketentuan pembuktian nilai pabean secara tegas. Ketentuan pembuktian harus dimuat dalam Pasal-pasal UU Kepabeanan sebagai dasar hukum penetapan nilai pabean guna memberikan kepastian hukum dan keadilan serta kemanfaatan hukum bagi masyarakat secara umum, sehingga dapat menjadi dasar hukum yang jelas dan pasti bagi importir dan pejabat bea cukai serta Pengadilan Pajak dalam melakukan penetapan nilai pabean.

\section{b.Prosedur Penelitian Nilai Pabean dan Pengawasannya}

WTO Valuation Agreement merumuskan ketentuan mengenai prosedur penetapan dan prosedur pengawasan yang harus dijalankan. Fungsi nilai pabean harus sepenuhnya diintegrasikan ke dalam seluruh praktek dan struktur kepabeanan, pada intinya mengatur sejumlah persyaratan legislasi domestik sebagai berikut: ${ }^{24}$

1. Importir bertanggung jawab untuk memberitahukan nilai 
impor sesuai dengan WTO Valuation Agreement. ${ }^{25}$

2. Pemeriksaan Nilai Pabean pada saat clearance harus terbatas dan selektif, dan pengeluaran barang tidak boleh terhambat karena sengketa nilai pabean, dan dimungkinkan clearance dengan mempertaruhkan jaminan atau deposit. $^{26}$

3. Verifikasi secara selektif dan audit pasca importasi diterapkan dengan profilling komoditi atau importir berdasarkan informasi dari sistem manajemen risiko.

4. Bea Cukai perlu membangun sistem informasi yang komprehensif dan database. Informasi dan data yang diperlukan: untuk membantu mendeteksi kasus underinvoicing atau overinvoicing, untuk menguji kewajaran nilai pabean guna penerapan Pasal 2 Agreement (metode barang identik) dan Pasal 3 agreement (metode barang serupa), untuk mengembangkan dan memperbarui analisis risiko dan sistem manajemen, dan untuk mengoptimalisasi peran kantor pusat dan kantor regional untuk merespon kesulitan dari kantor pelayanan.

\section{c. Struktur Organisasi dan Pelatihan}

Struktur organisasi yang direkomendasikan oleh Luc De Wulf dan Jose B. Sokol dalam bukunya Customs Modernization Handbook adalah pembentukan central valuation office dilengkapi dengan kantor wilayah dan kantor pelayanan. Hal ini diperlukan dalam kaitannya dengan luasnya wilayah dan struktur organisasi

\footnotetext{
${ }^{25}$ WTO,Opcit., Article 17

${ }^{26}$ WTO,Opcit., Pasal 13
}

administrasi pabean secara keseluruhan. Kantor pabean pusat bertanggung jawab untuk menetapkan kebijakan nilai pabean, pengembangan prosedur, pengawasan pelaksanaan yang benar dan seragam oleh semua kantor, memastikan pelatihan yang memadai, dan pemantauan perkembangan internasional terkait nilai pabean. Harus pula dikembangkan suatu database nilai pabean dan bertanggung jawab terhadap sistem manajemen risiko nilai pabean. Kantorkantor wilayah dan pelayanan memiliki peran operasional. Kompleksitas WTO Valuation Agreement dan pelaksanaan post clearance audit membutuhkan tenaga spesialis nilai pabean yang terlatih dalam memahami hukum nilai pabean dan prosedur serta audit keuangan perusahaan.

\section{d. Penguatan Komitmen}

Luc De Wulf dan Jose B. Sokol dalam bukunya Customs Modernization Handbook mengungkapkan kurangnya rasa memiliki negara berkembang atas WTO Valuation Agreement timbul dari sejarah penolakan atas adanya kekhawatiran mereka yang mana tidak bisa sepenuhnya diatasi. Namun, berbagai upaya terus dilakukan untuk mengatasi beberapa kesulitan tersebut. Pada negosiasi Putaran Uruguay, negara-negara berkembang menekankan untuk dilakukan perubahan dengan beberapa hasil, termasuk ketentuan beban pembuktian. Hal ini harus terus dilanjutkan. Salah satu cara untuk melakukannya negaranegara berkembang dengan jelas merumuskan kendala-kendala dalam melaksanakan WTO Valuation Agreement pada negosiasi perdagangan WTO berikutnya dan menyarankan pendekatan praktis untuk menerapkan semangat WTO Valuation Agreement 
tersebut. Hal ini dapat dimulai dengan mengidentifikasi kemungkinan dimana pihak pabean dapat membantu satu sama lain dengan pertukaran data dan inisiatif modernisasi. Hal tersebut terus diupayakan penyelesaiannya dalam proposal yang dirumuskan pada Konferensi Doha. Hasil tersebut menjadi penting untuk negara industri anggota WTO untuk mengakui bahwa negara-negara berkembang menghadapi masalah nyata dalam menerapkan ketentuan WTO Valuation Agreement. ${ }^{27}$

\section{e. Liberalisasi tarif dan Sinergisitas dengan Administrasi Perpajakan \\ Pendorong untuk melakukan} underinvoice atau penghindaran bea masuk terutama berasal dari tarif yang tinggi dan adanya pembatasan perdagangan berdasarkan nilai barang. Tarif impor yang rendah dan regulasi impor yang lebih liberal akan meminimalisasi masalah underinvoicing dan kerugian negara yang ditimbulkan. Penguatan regulasi pajak tidak langsung (pajak pertambahan nilai atau PPN) bisa membantu mengembalikan kerugian negara yang timbul dari tarif impor yang lebih rendah. PPN juga dikenakan pada tahap impor dan menghadapi risiko undervaluation, tapi kerugian pendapatan negara biasanya dapat diselamatkan kembali ketika transaksi tersebut dikenakan pajak pada tahap selanjutnya dari produksi dan rantai distribusi pendapatan melalui verifikasi atau pemeriksaan audit pasca impotasi. Namun demikian, terhadap barangbarang yang tidak terkena pajak atau perdagangan informal (pengusaha non PKP) misalnya, memang terdapat

\footnotetext{
${ }^{27}$ WTO, Opcit
}

kesulitan untuk memulihkan kerugian Negara dengan hasil pajak penjualan. ${ }^{28}$

\section{f. Modernisasi Pabean}

Aksi kunci yang diperlukan dalam modernisasi administrasi pabean terdiri dari perencanaan dan implementasi nilai pabean sesuai comprehensive customs modernization program. Fungsi Nilai Pabean tidak dapat bekerja secara terpisah dengan keseluruhan operasional dan sistem manajemen Pabean. Kemampuan untuk secara efektif melakukan fungsi nilai pabean secara langsung berkaitan dengan kualitas keseluruhan Administrasi Pabean. Sebuah program modernisasi harus mencakup unsur-unsur utama sebagai berikut:

1. Simplifikasi dan komputerisasi prosedur operasional

2. Penerapan strategi clearance yang modern, yaitu: pemeriksaan selektif berdasarkan analisis risiko dan manajemen, dan pemeriksaan pasca importasi.

3. Profesionalisme pejabat pabean melalui rekrutmen personil yang tepat, pengembangan, dan kebijakan manajemen, remunerasi yang lebih baik, pelatihan yang memadai dan berkelanjutan, dan pengendalian kepatuhan internal.

4. Pembentukan organisasi modern dan manajemen berdasarkan akuntabilitas administrasi, keuangan, dan kemandirian (otonomi teknis).

Untuk program modernisasi yang komprehensif sampai dengan hasil yang sukses, dukungan yang kuat dan berkelanjutan dari pimpinan pemerintah sangat penting. Selanjutnya, program tersebut idealnya harus didukung Technical Assistant dan dilaksanakan dengan bantuan

${ }^{28}$ Luc De Wulf, Jose B. Sokol, ibid. 
organisasi berpengalaman dalam melaksanakan proyek-proyek reformasi administrasi pabean. Beberapa negara juga telah memilih untuk sementara waktu menggunakan Pre Shipment Inspection (PSI) guna membantu pengumpulan informasi harga dan juga dengan pengembangan database selama tahun-tahun pertama program pelaksanaan customs administration tersebut.

\section{g. Penerapan advance ruling terkait Nilai Pabean}

Memfasilitasi importir dengan advance ruling pada proses penelitian nilai pabean juga dapat mempercepat prosedur penilaian dan mengurangi potensi dispute. Keputusan advance ruling dapat diperoleh sebelumnya ketika importir mengajukan dokumentasi terkait transaksi kepada pejabat pabean. Setelah diberikan putusan advance ruling, importir menyampaikan pada pemberitahuan pabean pada tahap impor, sehingga tidak ada penelitian nilai pabean lebih lanjut yang perlu dilakukan, dengan demikian mempercepat prosedur pengeluaran dan meminimalkan potensi dispute.

\section{h. Pertukaran Informasi dengan Administrasi Pabean Negara Pengekspor}

Pada Konferensi Tingkat Menteri Doha diserahkan proposal untuk solusi multilateral dalam kerangka WTO Valuation Agreement yang akan memungkinkan administrasi pabean negara pengimpor untuk mencari dan mendapatkan informasi tentang harga yang sebenarnya dalam deklarasi ekspor (PEB), yang terindikasi under/ overinvoicing. Upaya sebelumnya agar anggota WCO dapat saling membantu satu sama lain di bidang pencegahan, investigasi, dan penindakan belum berhasil. Telah banyak negara anggota meratifikasi ketentuan yang berkaitan dengan pemalsuan harga (fraud). Sebagian besar negara-negara industri belum melakukannya. Proposal Doha dimaksudkan untuk mengharmonisasi ketentuan WTO Valuation Agreement dengan kewajiban yang mengikat negara-negara anggota dalam memberikan bantuan penelitian nilai pabean dalam kasus dugaan pemalsuan harga.

WCO Council telah mengadopsi Konvensi Internasional tentang Bantuan Administratif Timbal Balik di Bidang Kepabeanan pada bulan Juni 2003. Ini termasuk ketentuan yang mengatur bantuan dalam memberikan informasi untuk penilaian impor atau ekspor untuk bea masuk dan pajak. Namun demikian konvensi ini belum diratifikasi, sehingga masih terlalu dini untuk melihat bagaimana hal itu benarbenar bisa mengatasi masalah dari penerapan nilai pabean. ${ }^{29}$

Konferensi Tingkat Menteri Doha dalam Decision 8.3 sepakat bahwa administrasi pabean dapat meminta bantuan dari administrasi pabean Negara pengekspor terhadap nilai barang tersebut, dan bahwa Negara anggota pengekspor menawarkan kerjasama dan bantuan, sesuai dengan hukum dan prosedur dalam negeri, termasuk menyediakan informasi pada nilai ekspor barang yang bersangkutan. Sebagai hasil dari diskusi tersebut, Komite Nilai Pabean WTO dan Komite Teknis Nilai Pabean WCO diamanatkan untuk mengidentifikasi dan menilai langkah-langkah praktis untuk mengatasi kekhawatirankekhawatiran beberapa negara-negara berkembang mengenai akurasi nilai

\footnotetext{
${ }^{29}$ WTO, Opcit. Article 10
} 
yang diberitahukan, termasuk pertukaran informasi dan pedoman untuk penggunaan database nilai
pabean.

\section{Kesimpulan}

Dari semua uraian yang telah dijelaskan pada bab-bab terdahulu, maka dapat diambil kesimpulan sebagai berikut:

a. Ketentuan pembuktian nilai pabean dalam UU Kepabeanan (domestic law) dan ketentuan WTO adalah sebagai:

1) Ketentuan pembuktian nilai pabean dalam UU Kepabeanan mengatur bahwa pihak melakukan penetapan nilai pabean untuk penghitungan bea masuk (Pejabat/ yang Direktur Jenderal), harus memiliki bukti yang menjadi dasar dilakukannya penetapan sesuai Pasal 16, 17 dan 86A UU Kepabeanan. Terdapat ketentuan pembalikan beban pembuktian yaitu pada Penjelasan Pasal 84 ayat (1) UU Kepabeanan yang menyatakan "Dalam hal permintaan pejabat bea dan cukai sebagaimana dimaksud di atas tidak dipenuhi pejabat bea dan cukai akan melakukan penetapan tarif dan/atau nilai pabean berdasarkan data yang ada. Namun penjelasan tidak dapat digunakan sebagai dasar hukum untuk membuat peraturan lebih lanjut dan tidak boleh mencantumkan rumusan yang berisi norma.

30 Ministerial Conference, Fourth Session, November 14, 2001
2) Sedangkan pada Peraturan Menteri Keuangan Nomor 160/PMK.04/2010 pembalikan beban pembuktian diatur pada Pasal 28 dan 31. Ketentuan tersebut menyatakan apabila pada saat pemeriksaan pemberitahuan pabean importir tidak memenuhi permintaan pejabat bea dan cukai atau Direktur Jenderal untuk menyerahkan semua informasi, dokumen, dan/atau pernyataan yang diperlukan dalam rangka penentuan nilai pabean maka Pejabat Bea dan Cukai menetapkan nilai pabean berdasarkan nilai transaksi barang identik sampai dengan metode pengulangan sesuai hierarki penggunaannya dan Direktur Jenderal dapat menggunakan data yang tersedia di dalam Daerah Pabean untuk menetapkan kembali nilai pabean.

3) Berdasarkan ketentuan WTO Valuation Agreement, ministerial decision 6.1 dan case study 13.1 dimungkinkan diterapkannya pembalikan beban pembuktian (reversal the burden of proof) atau pergeseran beban pembuktian (shifting the burden of proof) kepada pihak impotir. Apabila pada saat pemeriksaan pemberitahuan pabean importir tidak memenuhi permintaan bea dan cukai untuk menyerahkan semua informasi, dokumen, dan/atau pernyataan yang diperlukan dalam rangka penentuan nilai pabean maka nilai transaksi barang impor yang diberitahukan oleh 
Pemohon tidak dapat diterima sehingga digunakan metode alternative.

4) Mengingat peraturan mengenai Nilai Pabean dalam WTO Valuation Agreement dan Keputusan Komite Teknis Nilai Pabean WTO dan WCO telah cukup jelas dan rinci mengatur teknis dan tatacara penetapan nilai pabean maka peraturan nasional (peraturan teknis nilai pabean) yang menjelaskan mengenai tata cara pembuktian nilai pabean harus diadakan review agar sesuai dengan prinsip-prinsip International Best Practice. Berdasarkan Case Study 13.1. Proses ideal penetapan nilai pabean seharusnya dilakukan dalam proses audit (post clearance audit). Penggunaan mekanisme audit untuk menerapkan pembuktian nilai pabean agar menjadi kebijakan nasional dan pada akhirnya mengurangi kekalahan DJBC di Pengadilan Pajak.

\section{E. Bibliografi}

ASEAN, ASEAN Customs Valuation Guide. ASEAN Secretary, 2019.

Budi Nugroho \& Muhammad Hikmah, Kajian Akademis Faktor Penyebab Kekalahan Direktorat Jenderal Bea Dan Cukai Dalam Penyelesaian Sengketa Kepabeanan Melalui Pengadilan Pajak Tahun 2013 (Jakarta: Badan Pendidikan Dan Pelatihan Keuangan, 2014).

Cerah Bangun, Tranformasi Penyelesaian Sengketa Nilai Pabean (Studi Sengketa Nilai Pabean di Pengadilan Pajak).
Disertasi Program Doktor Ilmu Hukum Fakultas Hukum Universitas Indonesia, 2018

Frank J Garcia, Trade, Inequality, and Justice: Toward a Liberal Theory of Just Trade, (New York: Transnational Publishers, 2003)

Jimly Asshiddiqie, Teori Hans Kelsen tentang Hukum, (Jakarta: Penerbit Sekretariat Jenderal dan Kepaniteraan Mahkamah Konstitusi, 2006)

Luc De Wulf, Jose B. Sokol, 2005, Customs Modernization Handbook, Washington, D.C., The World Bank

Machmud, Syahrul, Hukum Acara Khusus pada Pengadilan Hubungan Industrial, (Yogyakarta: Graha Ilmu, 2014)

Mertokusumo, Soedikno, Hukum Acara Perdata, (Yogyakarta: Liberty, 2002)

Mochtar Kusumaatmadja, Fungsi dan Perkembangan Hukum Dalam Pembangunan Nasional, (Bandung: Bina Cipta, tanpa tahun)

Mohamad Jafar, Mengurai Benang Kusut Penerapan Nilai Pabean Berdasarkan Nilai Transaksi (Jakarta : Badan Pendidikan dan Pelatihan Keuangan Pusdiklat Bea dan Cukai,2011)

Muhjad Hadin, Penelitian Hukum Indonesia Kontemporer, (Yoyakarta: Genta Publishing. 2012)

Pudyatmoko, Y. Sri, Pengadilan dan Penyelesaian Sengketa di Bidang Pajak, Edisi Revisi, 2009, (Jakarta: Gramedia Pustaka Utama, 2005),

R. Soeroso, Pengantar Ilmu Hukum, (Jakarta: Sinar Grafika, 2013) 
Rahmat Trijono, Dasar-dasar Ilmu Pengetahuan Perundanganundangan. (Jakarta: Penerbit Papas Sinar Sinanti, 2013)

Roscoe Pound, Tugas Hukum, (Jakarta: Bhratara, 1965)

Salim HS dan Erlies Septiana Nurbani. Penerapan Teori Hukum pada Penelitian Tesis dan Disertasi. (Jakarta: Raja Grafindo, 2013)

Sheri Rosenow, Brian J. O'Shea, 2010, "A Handbook on WTO Customs Valuation Agreement - World Trade Organization"

Sudikno Mertokusumo dan A. Pitlo, Bab-bab Tentang Penemuan Hukum, (Bandung: Citra Aditya Bakti, 1993)

Sylviana Kusuma Lestari, Tinjauan Yuridis Atas Perlindungan Hukum Terhadap Industri Dalam Negeri Melalui Peraturan Nasional Dikaitkan Dengan Upaya Safeguards, (thesis pasca sarjana Universitas Indonesia, Jakarta, 2010)

Undang - Undang Tentang Kekuasaan Kehakiman, UU Nomor 4 Tahun 2004, LN no 8 tahun 2004 jo. Undang-Undang Nomor 48 Tahun 2009, LN no.157 tahun 2009

Undang - Undang Tentang Kepabeanan, UU No.10 Tahun 1995 LN No.75 Tahun 1995,TLN No.3612 sebagaimana telah diubah dengan UU No.17 Tahun 2006 LN No.93 Tahun 2006, TLN No.4661.

Undang - Undang Tentang Pengadilan Pajak, UU No. 14 tahun 2002, LN No.27 Tahun 2002.

Undang - Undang Tentang Perjanjian Internasional, UU No. 24 tahun 2000 LN no. 185 tahun 2000.

Undang-undang Dasar RI 1945
Undang-Undang Republik Indonesia Nomor 6 Tahun 1983 Tentang Ketentuan Umum Dan Tata Cara Perpajakan Sebagaimana Telah Beberapa Kali Diubah Terakhir Dengan Undang-Undang Republik Indonesia Nomor 16 Tahun 2009

Undang-Undang tentang Pengesahan Agreement Establishing The World Trade Organization (Persetujuan Pembentukan Organisasi Perdagangan Dunia), Undang-Undang Nomor 7 Tahun 1994, Lembaran Negara Republik Indonesia Tahun 1994 Nomor 57, Tambahan LembaranNegara Republik Indonesia Nomor 3564.

Utrecht, E., Pengantar Hukum Administrasi Negara Indonesia (Surabaya: Pustaka Tinta Mahkamah Agung, 1994) 258.

Zainuddin Ali, Metode Penelitian Hukum (Jakarta: Penerbit Sinar Grafika, 2011) Cet.3. 